Research Article

\title{
Plasmon-Enhanced Efficiency in Dye Sensitized Solar Cells Decorated with Size-Controlled Silver Nanoparticles Based on Anthocyanins as Light Harvesting Pigment
}

\author{
Eli Danladi“, Joshua Adeyemi Owolabi, Gabriel Olawale Olowomofe, Ezeoke Jonathan \\ Department of Physics, Nigerian Defence Academy, Kaduna, Nigeria \\ Email address: \\ danladielibako@gmail.com (E. Danladi) \\ *Corresponding author
}

To cite this article:

Eli Danladi, Joshua Adeyemi Owolabi, Gabriel Olawale Olowomofe, Ezeoke Jonathan. Plasmon-Enhanced Efficiency in Dye Sensitized Solar Cells Decorated with Size-Controlled Silver Nanoparticles Based on Anthocyanins as Light Harvesting Pigment. Journal of Photonic Materials and Technology. Vol. 2, No. 1, 2016, pp. 6-13. doi: 10.11648/j.jmpt.20160201.12

Received: June 30, 2016; Accepted: July 14, 2016; Published: August 11, 2016

\begin{abstract}
The enhancement in efficiency of dye sensitized solar cells modified with silver nanoparticles based on anthocyanins as light harvesting pigment through successive ionic layer adsorption and reaction (SILAR) was demonstrated. Studies indicate that, the short-circuit current density $\left(J_{S C}\right)$ and open-circuit voltage $\left(V_{O C}\right)$, of DSSCs containing AgNPs were significantly improved. The photovoltaic (PV) performance decreased with increasing cycle of AgNPs from one SILAR cycle to two SILAR cycles. The best device was achieved using the photoanode prepared with one SILAR cycle. An enhancement of $35.8 \%$ was achieved when the thickness was around $16 \mathrm{~nm}$ (one SILAR) over the bare FTO device. When the size of AgNPs was around $32 \mathrm{~nm}$ (two SILAR), an enhancement of $10.4 \%$ was recorded over the reference device. This selective enhancement in efficiency in the Ag plasmonic absorption regions is indicative of the fact that the incorporation of metal nanoparticles is beneficial for enhanced absorption and charge separation.
\end{abstract}

Keywords: Nanocomposite, SPR, Intensified Near Field, DSSCs, Silver Nanoparticles, Anthocyanins

\section{Introduction}

Solar cell technologies have been categorized into three generations [1]. The first generation photovoltaic solar cells are based on a single crystalline semiconductor wafer. The second generation solar cells utilize thin layer of polycrystalline semiconductor, they are cheaper to produce, flexible and lightweight; however the efficiency is still lower than first generation cells. The third generation solar cell also known as Grätzel cells or dye-sensitized solar cells was successfully achieved by combination of nanostructured electrodes and efficient charge injecting dyes [2].

However, the low efficiency of conversion and stability are the major problems confronting the third generation solar cell.

Facilitating means in achieving higher efficiencies are channeled in optimizing the morphology of the active photovoltaic layer and the charge transport properties of the absorber through (i) thermal annealing treatment, (ii) use of various solvents, (iii) the use of additives and (iv) the process conditions [3-10]. Plasmonic introduction in photoactive layers of DSSC, to trap or confine light inside the active layer and enhance the absorption in the semiconductor film could result to enhanced device performances [11-22] likely due to their unique electronic, optical and magnetic properties [10, $11]$.

This surface plasmon resonance is dependent on the shape, size and distribution of the NPs as well as on the dielectric functions of the metal and the dielectric surrounding environment [23].

In attempt to optimize the device performance and stability, several of light harvesting materials are used to improve its photovoltaic performance and investigate their properties, since they play a very important role in harvesting sunlight and transforming solar energy into electric energy.

In addition, the dye is an important part of the DSSCs, 
playing a significant role in absorbing light, generating photo-stimulated carriers and injecting these carriers into the conduction band of $\mathrm{TiO}_{2}$ network. Thus, the light absorption capability of the dye and how many carriers it stimulates directly affect carrier injection and DSSCs performance [14]. Therefore, enhancing dye light absorption should be an effective way to increase the conversion efficiency.

The use of natural dyes have been considered as potential candidates to enhance the light response of semiconductor in active layers of solar cells, and have been demonstrated on several solar-cell materials [24-33].

Here anthocyanins pigment present in Hibiscus Sabdariffa extract was considered as the sensitizer due to its light harvesting capability in the visible region of the electromagnetic spectrum. Hibiscus Sabdariffa extract is rich in anthocyanins. It was reported that anthocyanin obtained from Roselle are delphinidin and cyanidin complexes [34, 35]. The chemical structure of cyanidin and delphinidin in the Hibiscus Sabdariffa dye is shown in Figure 1 [31]. It is characterized by the presence of $(-\mathrm{OH})$ functional group which allows short distance between the dye skeleton and the point connected to $\mathrm{TiO}_{2}$ surface, thus enhancing the binding interaction between the pigment and the $\mathrm{TiO}_{2}$ film, which brings about good electronic coupling and electron transfer reaction in the visible spectrum.

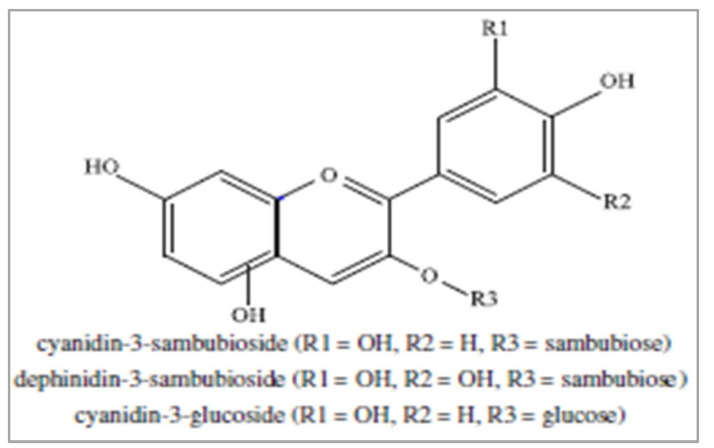

Figure 1. Chemical structures of: cyanidin and delphinidin in rosella dye.

In this present work the performance of DSSC, based on anthocyanins as light harvesting pigment when size-controlled silver nanoparticles (NPs) are incorporated into the $\mathrm{TiO}_{2}$ mesoporous layer of the device structure was compared. Inclusion of AgNPs into the photoanode revealed better overall performance with an increased efficiency of $35.8 \%$ with $16 \mathrm{~nm}$ size. When the size of Ag-NPs was around $32 \mathrm{~nm}$ size, an improvement of $10.4 \%$ in efficiency was demonstrated over the performance of the reference cell. The related PV performance mechanisms in DSSCs with Ag nanostructures are analysed and discussed.

\section{Materials and Methods}

\subsection{Materials}

Silver nitrate $\left(\mathrm{AgNO}_{3}\right)$, and ethanol (99.8\%), were purchased from Sigma-Aldrich and used as received. Hydrochloric acid ( $\mathrm{HCl}) 36 \%$, sodium lauryl sulphate (SLES),
Tetraoxosulphate (iv) acid $\left(\mathrm{H}_{2} \mathrm{SO}_{4}\right) 96 \%$, acetonitrile, sodium silicate, Platisol, silicon dioxide, Titanium tetra chloride, acetaldehyde, Tin chloride, Chromic Acid were purchased from BDH chemicals. FTO was purchased from solaronix. The surface resistance of the FTO was $8 \mathrm{ohms} / \mathrm{m}^{2}, \mathrm{P} 25 \mathrm{TiO}_{2}$ powder was obtained from Alfa Aesar.

\subsection{Dye Extraction}

The flowers of Hibiscus Sabdariffa were air dried till they became invariant in weight. The dried flowers of Hibiscus were left uncrushed because previous attempts proved failure to extract the dye from crushed samples due to jellification [32]. The method of heating in water was used to extract the dye. Distilled water was the solvent for aqueous extraction. $5 \mathrm{~g}$ of the sample (Dried Hibiscus Sabdariffa) was measured using analytical scale and dipped in $50 \mathrm{ml}$ of the solvent heated to $100^{\circ} \mathrm{C}$ for $30 \mathrm{~min}$ after which solid residues were filtered out to obtain clear dye solutions.

\subsection{Synthesis of Nanocomposite Material}

Dip coating method was used to synthesize the Ag nanocomposite on the glass substrate. The microscope slide was cleaned with sodium lauryl sulphate (SLES) solution and then rinsed with deionized water three times. Thereafter dipped into a beaker containing a mixture of 2 moles concentrated Tetraoxosulphate (iv) acid and 2 moles chromic acid to make the surface hydrophilic for 10 minutes, the sample was thereafter rinsed with distilled water. After making it hydrophilic, it was immersed in 2 moles Tin chloride $\left(\mathrm{SnCl}_{2}\right)$ for 2 minutes then rinsed with distilled water for 2 minutes, then immersed in 0.35 mole silver nitrate $\left(\mathrm{AgNO}_{3}\right)$ for 2 minutes and rinsed with mixture of $150 \mathrm{ml}$ distilled water $\left(\mathrm{H}_{2} \mathrm{O}\right)$ and 0.4 moles hydrochloric acid $(\mathrm{HCl})$ for 15 seconds. This procedure is called one cycle. It was repeated for two cycles.

\subsection{Fabrication of the DSSCs}

The sample of $\mathrm{TiO}_{2}$ was prepared by the sol-gel technique in which $2 \mathrm{~g}$ of $\mathrm{P} 25 \mathrm{TiO}_{2}$ powder was dissolved in $10 \mathrm{ml}$ of deionized water mixed with $0.2 \mathrm{ml}$ of Triton-X 100 and $0.4 \mathrm{ml}$ of acetaldehyde, then vibrated ultrasonically using magnetic stirrer hotplate for 24 hours. The silver modified DSSCs were fabricated on FTO glass with the structure of FTO/TiO $/ 2 / \mathrm{AgNPs}$ with different SILAR cycles. As reference sample, the device with architecture of $\mathrm{FTO} / \mathrm{TiO}_{2}$ was fabricated. The FTO glass substrate was first cleaned with deionized water and ultrasonicated in isopropanol for about 15 minutes. Motivated by this analysis, we utilized SILAR and screen printing method to achieve the design of $\mathrm{FTO} / \mathrm{TiO}_{2} / \mathrm{AgNPs}$. To create the particles, a 16 and $32 \mathrm{~nm}$ layer of the silver metal film was deposited onto $\mathrm{TiO}_{2}$ through successive ionic layer adsorption and reaction and annealed at $450^{\circ} \mathrm{C}$ for 30 minutes. $\mathrm{TiCl}_{4}(40$ mmoles) was spin coated at 2500 rounds/minute for 30 seconds and then sintered at $450^{\circ} \mathrm{C}$ for 30 minutes. To ensure the silver is protected, we treated it with 40 mmoles solution of $\mathrm{TiCl}_{4}$ prepared at $40^{\circ} \mathrm{C}$, then raised the temperature to $70^{\circ} \mathrm{C}$ and 
finally annealed at $300^{\circ} \mathrm{C}$ to $350^{\circ} \mathrm{C} . \mathrm{SiO}_{2}$ was deposited on the AgNPs using SILAR method with sodium silicate $\left(\mathrm{Na}_{2} \mathrm{O}\left(\mathrm{SiO}_{3}\right)\right)$ as the precursor. The minimum number of cycles that gave the cells stability was five cycles. The first cell with one Ag cycle had five cycles of $\mathrm{SiO}_{2}$, and the second cell with two AgNPs cycles had ten cycles of $\mathrm{SiO}_{2}$. The counter electrode was prepared by screen printing a platinum catalyst gel coating onto the FTO glass. It was then dried at $100^{\circ} \mathrm{C}$ and heated at $400^{\circ} \mathrm{C}$ for 30 minutes.

The cells were assembled by pressing the sensitized photo anode against the platinum-coated counter electrodes slightly offset to each other to enable electrical connection to the conductive side of the electrodes. Between the electrodes, a 50 $\mu \mathrm{m}$ space was retained using two layers of a thermostat hot melt sealing foil. Sealing was done by keeping the structure in a hot-pressed at $100^{\circ} \mathrm{C}$ for 1 minute. The liquid electrolyte constituted by $50 \mathrm{mM}$ of tri-iodide/iodide in acetonitrile was introduced by injection into the cell gap through a channel previously fabricated at opposite sides of the hot melt adhesive, the channel was then sealed.

\subsection{Characterization and Measurement}

The current density-voltage $(J-V)$ characteristics of the cells were recorded under an irradiance of $100 \mathrm{~mW} / \mathrm{cm}^{2}$ (AM1.5) simulated illumination (keithley 2400 source meter from a Newport A solar simulator). The surface morphologies of the $\mathrm{TiO}_{2}$ and $\mathrm{TiO}_{2}$ with different SILAR cycles of AgNPs photoanodes were observed by scanning electron microscopy (Phenom Pro X model, Eindhoven de Netherlands). The absorption spectra of the dye and various photoanode were recorded on Ava-spec-2048 spectrophotometer in the region of $350-1000 \mathrm{~nm}$. The effective irradiated area of each cell was $1.8 \mathrm{~cm}^{2}$. Thickness measurement was obtained with a Dektac 150 surface profiler.

\section{Results and Discussion}

Figure 2 depicts a representative ultraviolet (UV)-visible (vis) absorption spectra of Hibiscus Sabdariffa extract. The absorption peak of dye extract was observed around $550 \mathrm{~nm}$ (indicated in Figure 2) which ascertains the presence of anthocyanin pigment and in agreement with onimisi et al [13].

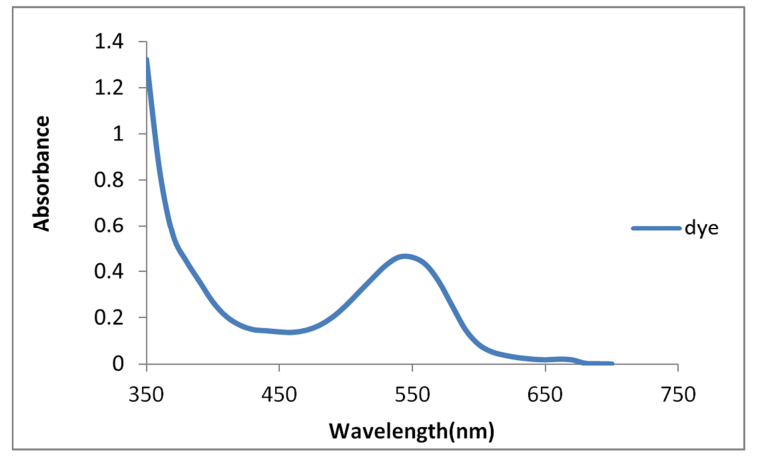

Figure 2. UV-Vis spectra of the dye.

Fig 3 shows the UV-vis absorption spectra of the $\mathrm{TiO}_{2}$ and $\mathrm{TiO}_{2}$ with different SILAR cycles of AgNPs within the wavelength range of $350-1000 \mathrm{~nm}$ in the absence of anthocyanin pigment along with the controlled size growth of the $\mathrm{Ag}$ particle from 16 to $32 \mathrm{~nm}$ which correspond to the number of cycles as shown in Figure 5
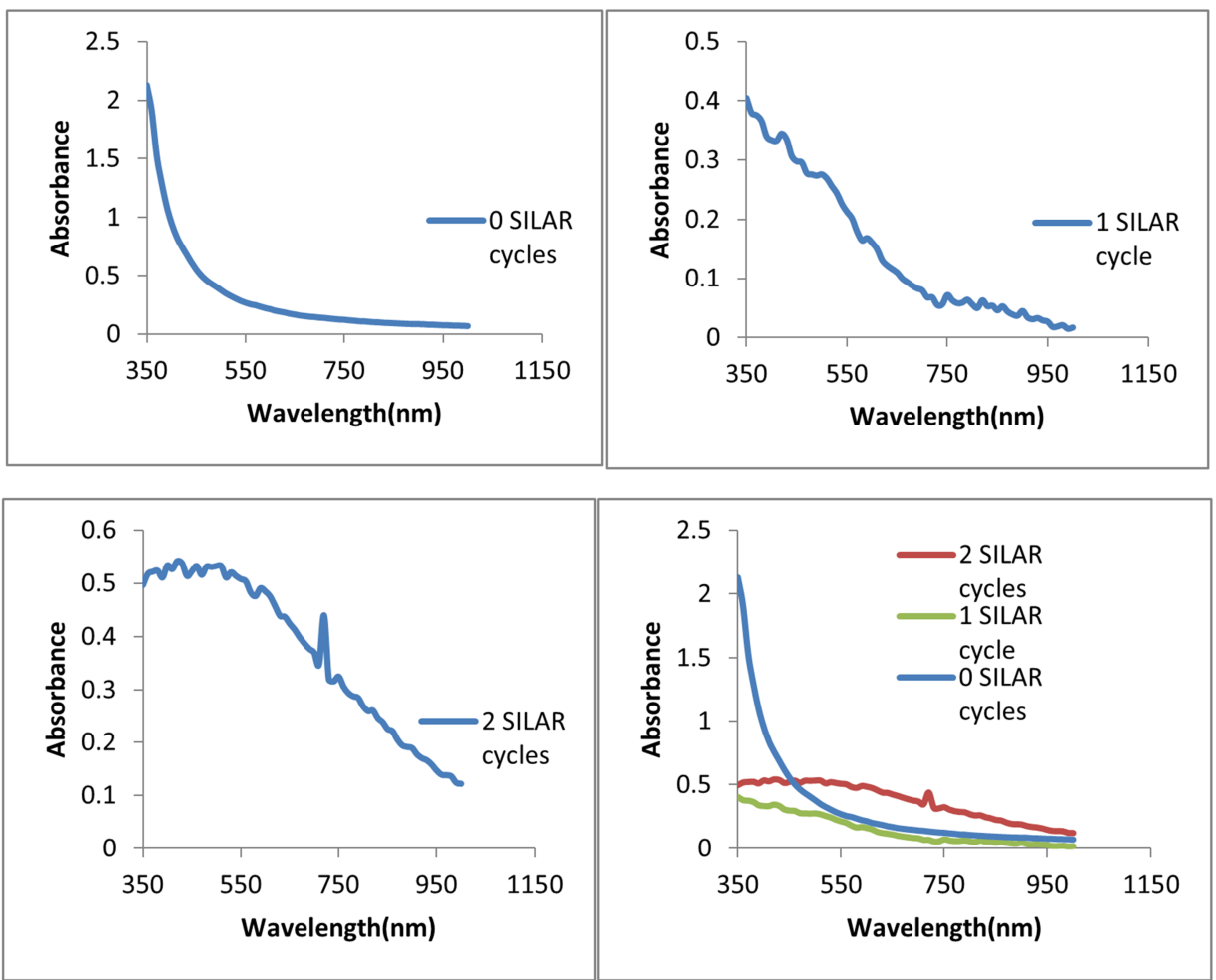

Figure 3. UV-vis spectra of various prepared Ag NPs suspensions without dye. 

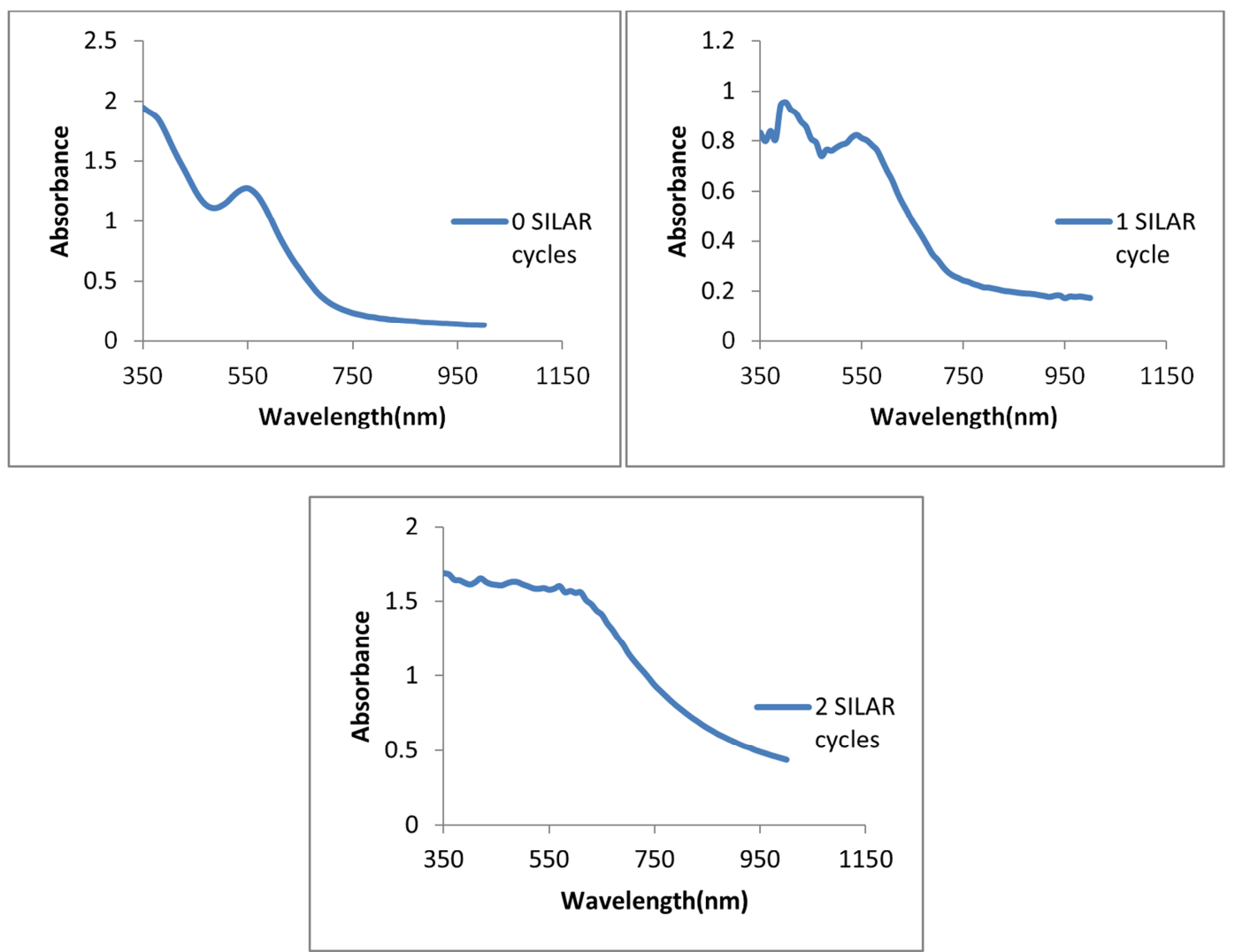

Figure 4. UV-vis spectra of various prepared Ag NPs suspensions with dye.

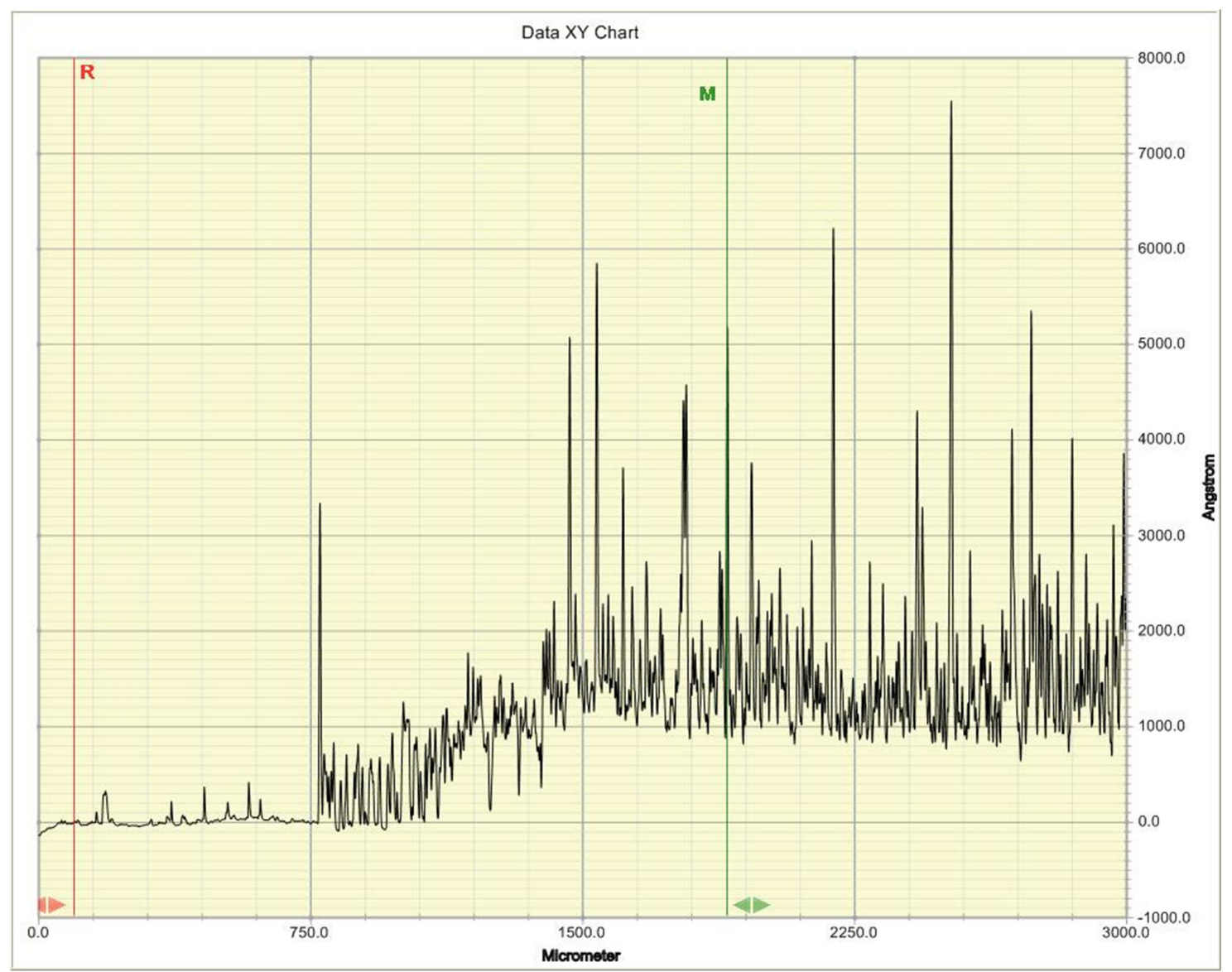

Figure 5. Thickness measurement of 10 SILAR cycles which shows the growth rate of 1 and 2 cycles. 
Fig 4 shows the UV-vis absorption spectra of $\mathrm{TiO}_{2}$ and $\mathrm{TiO}_{2}$ with size controlled AgNPs after sensitization. The absorption of the entire visible region for the electrode with different SILAR cycle of AgNPs was stronger than that for the electrode without AgNPs. The optical absorption enhancement was observed in the dye-loaded plasmonic nanocomposite films which is attributed to the SPR of metallic
AgNPs, which interacted with the dye molecule thereby enhancing dye absorption.

These properties exhibited above shows that dye molecules in the presence of metallic NPs can absorb more photons, possibly because of the intensified near-field effect of the surface plasmon and spectral overlap between the dye and SPR.
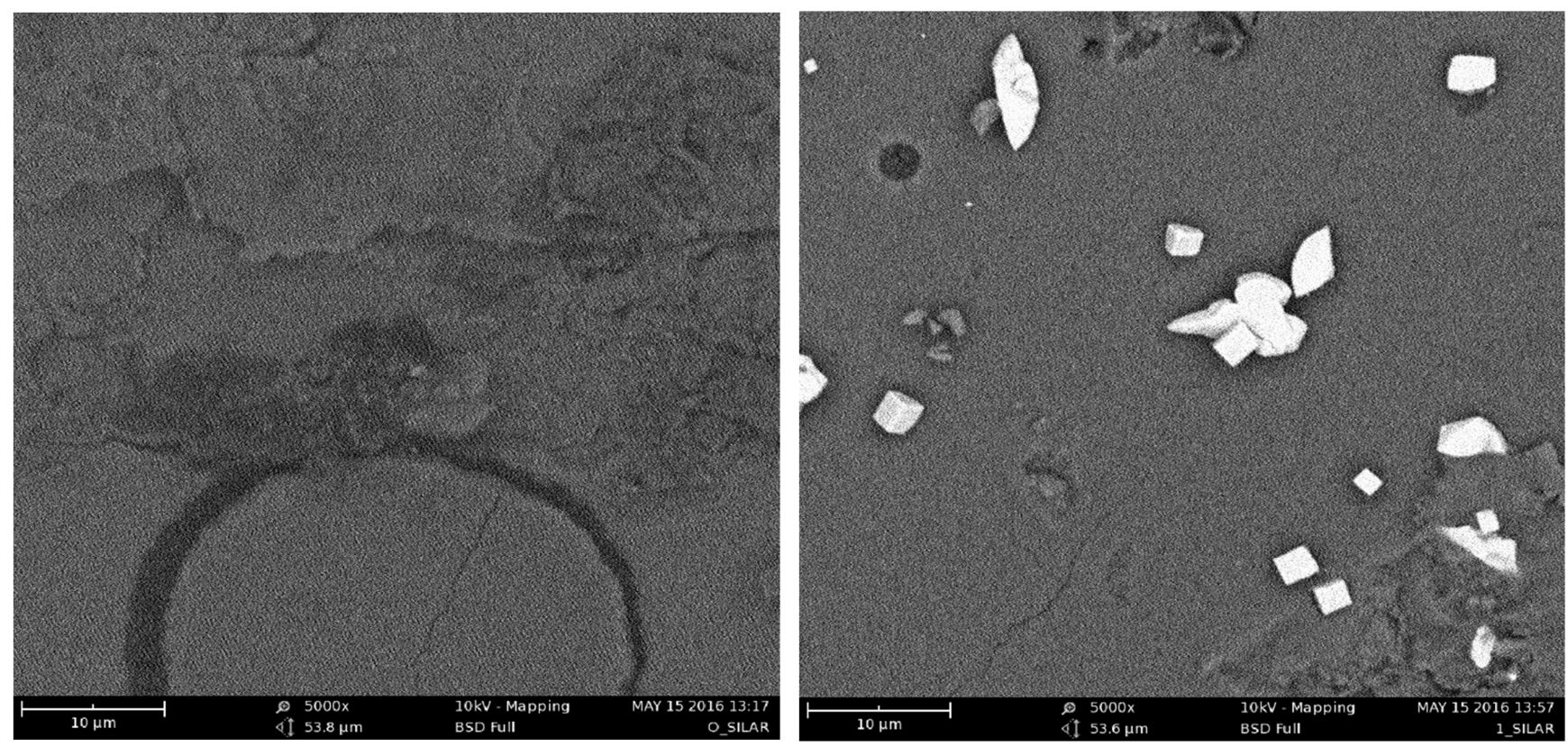

(a) (b)

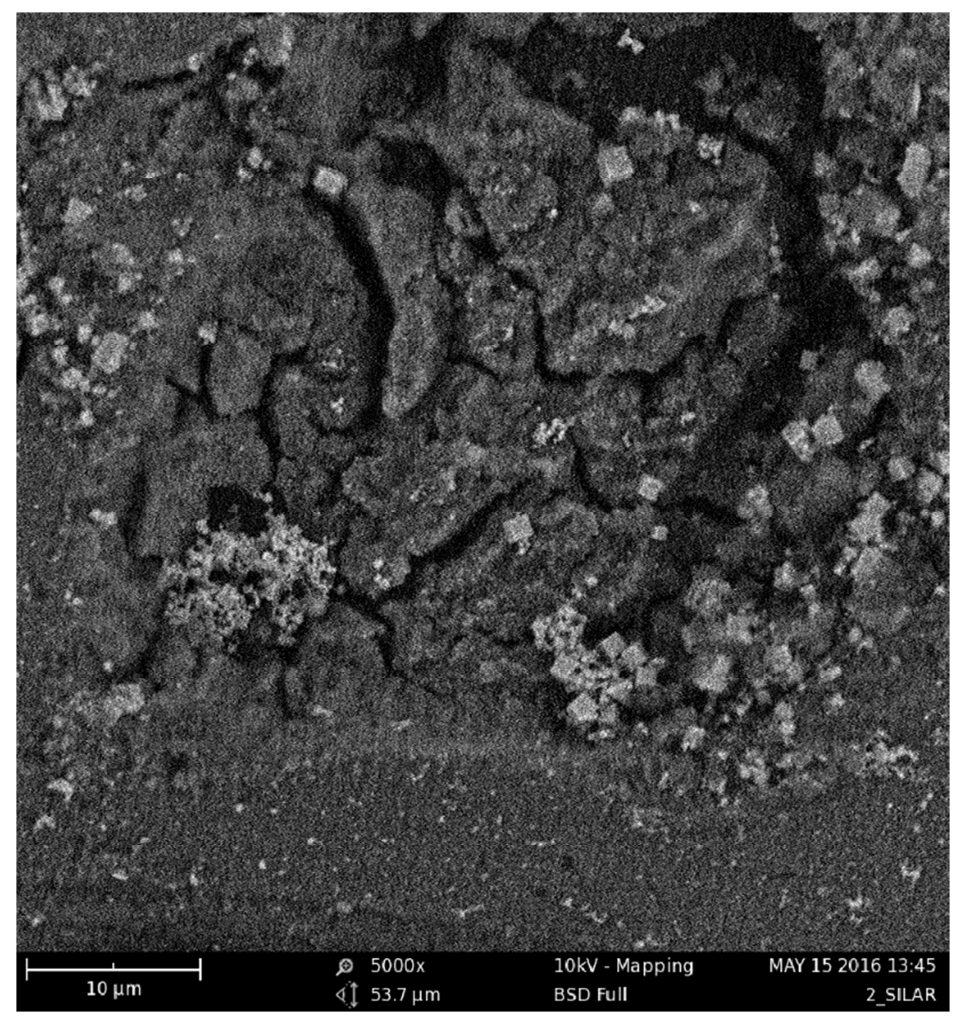

(c)

Figure 6. SEM images of (a) O SILAR cycle, (b) 1 SILAR cycles and (c) 2 cycles. 
Figure 6 shows the scanning electron microscope (SEM) image of $\mathrm{TiO}_{2}$ and $\mathrm{TiO}_{2}$ with $\mathrm{Ag}$ nanoparticles fabricated using screen printing and SILAR procedure. The image in Figure 6 shows the Ag nanoparticle with $0 \mathrm{~nm}, 16 \mathrm{~nm}$ and 32 $\mathrm{nm}$ sizes. The SEM image of Figure 6 (b) and (c) also reveals that the Ag clusters from NPs are randomly dispersed on the top surface of active layer with much islands on the device with two SILAR cycles.

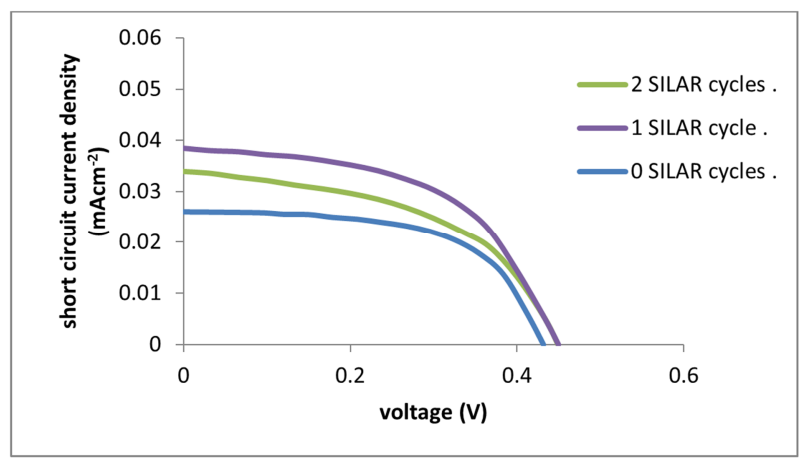

Figure 7. The photocurrent density-voltage $(J-V)$ curves with varying SILAR cycles.
Figure 7 shows the photocurrent density-voltage $(\mathrm{J}-\mathrm{V})$ curves of the DSSCs with varying SILAR cycles 0,1 , and 2 cycles. Based on the curves in Figure 3, the fill factor (FF) and solar cell efficiency $(\eta)$ were determined following the equations:

$$
\begin{gathered}
F F=\frac{P_{\max }}{P_{\text {in }}}=\frac{J_{\max } \times V_{\max }}{J_{S C} \times V_{O C}} \\
\eta=\frac{F F \times J_{S C} \times V_{O C}}{P_{\text {IRRADIANCE }}} .100 \%
\end{gathered}
$$

Where

$V_{\max }=$ maximum voltage $(\mathrm{V})$;

$J_{\max }=$ maximum current density $\left(\mathrm{mA} / \mathrm{cm}^{2}\right)$;

$J_{s c}=$ short circuit current density $\left(\mathrm{mA} / \mathrm{cm}^{2}\right)$;

$V_{o c}=$ open circuit voltage $(\mathrm{V})$ and

$P_{\text {IRRADIANCE }}=$ light intensity $\left(\mathrm{mW} / \mathrm{cm}^{2}\right)$

$P_{\max }=$ maximum power

$P_{\text {in }}=$ power input

Table 1. Performance characteristics of DSCs fabricated with different anodes under $100 \mathrm{mWcm}^{-2}$.

\begin{tabular}{lllll}
\hline Sample & $\boldsymbol{J}_{\mathbf{s c}}\left(\mathbf{m A c m}^{-2}\right)$ & $\boldsymbol{V}_{\boldsymbol{c c}}(\mathbf{V})$ & $\boldsymbol{F F}(\mathbf{\%})$ & $\eta(\%)$ \\
\hline $\mathrm{FTO} / \mathrm{TiO}_{2}$ & 0.026 & 0.432 & 59.4 & 0.0067 \\
$\mathrm{FTO} / \mathrm{TiO}_{2} / \mathrm{AgNPs}$ (1 SILAR) & 0.039 & 0.450 & 52.6 & 0.0091 \\
$\mathrm{FTO} / \mathrm{TiO}_{2} / \mathrm{AgNPs}$ (2 SILAR) & 0.034 & 0.449 & 48.8 & 0.0074 \\
\hline
\end{tabular}

The performance of the DSSCs based on only $\mathrm{TiO}_{2}$ and $\mathrm{Ag}$ modified $\mathrm{TiO}_{2}$ electrodes with one and two SILAR cycles were examined under 1 sun AM 1.5 simulated sunlight. Figure 7 and Table 1 compared the $J-V$ characteristics for DSSCs prepared with the $\mathrm{TiO}_{2}-\mathrm{Ag}$ with 1 and 2 cycles nanocomposite

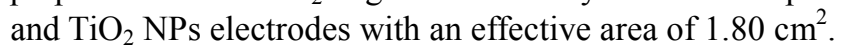

As demonstrated from Table 1, the photovoltaic parameters, especially the photocurrent, and open circuit voltage of DSSCs containing AgNPs was affected by the SILAR cycle of AgNPs. The PV performance decreased with increasing size of AgNPs from $16 \mathrm{~nm}$ to $32 \mathrm{~nm}$. From Table 1, the best performance was achieved using the device fabricated with 16 $\mathrm{nm}$ size of AgNPs. The best cell demonstrated a $J_{\mathrm{sc}}$ of 0.0385 $\mathrm{mAcm}^{-2}, V_{o}$ of $0.45 \mathrm{~V}$ and $F F$ of 0.526 , yielding the highest efficiency $(\eta)$ of $0.0091 \%$. The cell exhibits a $35.8 \%$ improvement over the performance of bare FTO-based device. The improvement in efficiency in the presence of AgNPs can be seen to arise from an increase in $J_{\mathrm{sc}}$ and $V_{o c}$ values. The enhanced $J_{s c}$ is related to the light harvesting capability of dye molecules by excitation of the SPR.

It is shown from Figure 7, that the mixed films containing $\mathrm{Ag}$ particles exhibit an increase in the power conversion efficiency from 10.4 to $35.8 \%$.

Silver has been known to have some catalytic ability, in our work, when $\mathrm{AgNP}$ was $16 \mathrm{~nm}$, the catalytic effect of AgNPs observed on $\mathrm{TiO}_{2}$ support could increase the reaction rate between the $\mathrm{TiO}_{2} /$ dye and the redox electrolyte in the formed DSSC, thereby reducing the corresponding electron transport resistance [14]. Conversely, as the silver size became larger (32 $\mathrm{nm}), \mathrm{AgNPs}$ easily aggregated and formed islands as shown in Figure $6 \mathrm{c}$, which could not preferentially attach to specific sites on the $\mathrm{TiO}_{2}$ surface, resulting in the decrease of catalytic activity thereby reducing the reaction rate between $\mathrm{TiO}_{2} /$ dye.

In addition, as the thickness of the film is around $32 \mathrm{~nm}$ the mixed films might result in blockage of sunlight which would prevent the incident light from reaching the $\mathrm{TiO}_{2}$ NPs effectively, resulting in the decrease in the photocurrent density. It was once reported that the decrease in efficiency due to increasing surface roughness was found to be proportional to the light transmittance [17]. As a consequence, the probability of electrons and holes to recombine may increase, so $J_{s c}$ and $V_{o c}$ would decrease. Also, higher concentrations of AgNPs may cluster to form larger AgNPs groups with lower electron storage capability, reducing $V_{o c}$ [18].

Also, as the size of the AgNPs was upto $32 \mathrm{~nm}$, not all of the AgNPs in photoanode were entirely coated by $\mathrm{TiO}_{2}$ to form the mixed film. Therefore, some of the bare AgNPs in the $\mathrm{AgTiO}_{2}$ network structure may be eroded by electrolyte and oxidized to $\mathrm{Ag}^{+}$ions [36]. This reduces the number of charge carriers, thereby acting as recombination centers, thus resulting in a decrease in $J_{s c}$ and $V_{o c}$. 
As shown in Table 1 above, for better perfomance, Metal plasmon must be $16 \mathrm{~nm}$ in size to escape recombination and produce an enhanced photovoltaic parameter. The electric field of localized plasmon resonances only promotes few dye molecules when the AgNPs size was $32 \mathrm{~nm}$, leading to limited enhancement. Therefore, light trapping of localized surface plasmon was mainly improved in DSSC fabricated with $\mathrm{FTO} / \mathrm{TiO}_{2} / \mathrm{AgNPs}(16 \mathrm{~nm})$ photoanode electrode in our system, leading to the enhanced photocurrent response in the whole visible region.

\section{Conclusions}

The impact of size-controlled AgNPs on the performance of DSSCs through successive ionic layer adsorption and reaction based on anthocyanins pigment was demonstrated. The photovoltaic performance was evaluated under $100 \mathrm{mWcm}^{-2}$ light intensity. The effect was studied in the system of modified size-controlled Ag inclusions inside the DSSC. The photovoltaic response of the nanocomposite with inhomogeneous distribution of coated two dimensional array cluster of NPs randomly dispersed on the top surface of active $\mathrm{TiO}_{2}$ nanoporous layer was analyzed.

The performance, especially the photocurrent, and open circuit voltage of the DSSC containing AgNPs was affected by the controlled sizes of AgNPs. The modified AgNPs photoanode with $16 \mathrm{~nm}$ thickness shows an efficiency of $0.0091 \%$ which represents a $35.8 \%$ improvement in efficiency over the DSSC without AgNPs. Also when the size of the AgNPs was $32 \mathrm{~nm}$, an efficiency of $0.0074 \%$ was achieved which represents a $10.4 \%$ improvement from the standard electrode without AgNPs.

\section{References}

[1] Jun, H. K., Careem, M. A., Arof, A. K. (2013). Quantum dot-sensitized solar cells perspective and recent developments: A review of $\mathrm{Cd}$ chalcogenide quantum dots as sensitizers. Renewable and Sustainable Energy Reviews 22, 148-167.

[2] Gratzel, M. (2003). Dye-sensitized solar cells. Journal of Photochemistry and Photobiology C: Photochemistry Reviews, $4,145-153$.

[3] Ma, W., Yang, C., Gong, X., Lee, K., \& Heeger, A. J. (2005). Thermally stable, efficient polymer solar cells with nanoscale control of the interpenetrating network morphology. Advanced Functional Materials, 15, 1617-1622.

[4] Li, G., Shrotriya, V., Yao, Y., \& Yang, Y. (2005). Investigation of annealing effects and film thickness dependence of polymer solar cells based on poly (3-hexylthio- phene). Journal of Applied Physics, 98, 043704-1-043704-5.

[5] Dang, M. T., Wantz, G., Bejbouji, H., Urien, M., Dautel, O. J., Vignau, L., \& Hirsch, L. (2011). Polymeric solar cells based on P3HT: PCBM: role of the casting solvent. Solar Energy Materials and Solar Cells, 95, 3408-3418.

[6] Lee, J. K., Ma, W. L., Brabec, C. J., Yuen, J., Moon, J. S., Kim, J. Y., Lee, K., Bazan, G. C., \& Heeger, A. J. (2008). Processing additives for improved efficiency from bulk hetero-junction solar cells. Journal of the American Chemical Society, 130, 3619-3623.

[7] Li, G., Shrotriya, V., Huang, J., Yao, Y., Moriarty, T., Emery, K., \& Yang, Y. (2005). High- efficiency solution processable polymer photovoltaic cells by self-organization of polymer blends. Nature Materials, 4, 864-868.

[8] Li, G., Shrotriya, V., Yao, Y., Huang, J., \& Yang, Y. (2007). Manipulatingregioregularpoly (3-hexylthiophene): [6, 6]-phenyl-C61-butyricacidmethylester blends - route towards high efficiency polymer solar cells. Journal of Materials Chemistry 17, 3126-3140.

[9] Shaheen, S. E., Brabec, C. J., Sariciftci, N. S., Padinger, F., Fromherz, T., \& Hummelen, J. C. (2001). 2.5\% efficient organic plastic solar cells. Applied Physics Letters, 78, 841843 .

[10] Li, G., Yao, Y., Yang, H., Shrotriya, V., Yang, G., \& Yang, Y. (2007). Solvent annealing effect in polymer solar cells based on poly (3-hexylthiophene) and methanofullerenes. Advanced Functional Materials, 17, 1636-1644.

[11] Danladi, E., Onimisi, M. Y., Abdu, S. G., Gyuk, P. M., \& Ezeoke, J. (2016). Enhanced performance of a dye sensitized solar cell using silver nanoparticles modified photoanode. Journal of Scientific Research \& Reports, 10(4), 1-8.

[12] Danladi, E., Ahmad, M. S., Ayiya, B. B., Babatunde, O. A. (2016). Plasmonic dye sensitized solar cells incorporated with $\mathrm{TiO}_{2}-\mathrm{Ag}$ nanostructures. International Research Journal of Pure \& Applied Chemistry, 11(3), 1-7.

[13] Onimisi, M. Y., Danladi, E., Abdu, S. G., Aboh, H. O., Ezeoke, J. (2016). Size effects of silver nanoparticles on the photovoltaic performance of dye sensitized solar cells. American Chemical Science Journal, 13(3), 1-8.

[14] Guo, K., Li, M., Fang, X., Liu, X., Sebo, B., Zhu, Y., Hu, Z., \& Zhao, X. (2013). Preparation and enhanced properties of dye-sensitized solar cells by surface plasmon resonance of $\mathrm{Ag}$ nanoparticles in nanocomposite photoanode. Journal of Power Sources, 230, 155-160.

[15] Lin, S. J., Lee, K. C., Wu, J. L., \& Wu. J. Y. (2012). Plasmon-enhanced photocurrent in dye-sensitized solar cells. Solar Energy, 86, 2600-2605.

[16] Chien, T. M., Pavaskar, P., Hung, W. H., Cronin, S., Chiu, S. H., \& Lai, S. N. (2015). Study of the Plasmon energy transfer processes in dye sensitized solar cells. Journal of nanomaterials, 2015, Article ID 139243.

[17] Kim, H. J., \& Kim, D. E. (2012). Effect of surface roughness of top cover layer on the efficiency of dye-sensitized solar cell. Solar energy, 86(7), 2049-2055

[18] Takai, A., \& Kamat, P. V. (2011). Capture, store and discharge. Shuttling photogenerated electrons across $\mathrm{TiO}_{2}-\mathrm{Ag}$ interface. ACS Nano, 5, 7369-7376.

[19] Westphalen, M., Kreibig, U., Rostalski, J., Luth, H., \& Meissner, D. (2000). Metal cluster enhanced organic solar cells. Solar Energy Materials and Solar Cells, 61, 97-105.

[20] Rand, B. P., Peumans, P., \& Forrest, S. R. (2004). Long-range absorption enhancement in organic tandem thin-film solar cells containing silver nanoclusters. Journal of Applied Physics, 96, 7519-7526. 
[21] Morfa, A. J., Rowlen, K. L., Reilly, T. H., Romero, M. J., \& vande Lagemaat, J. (2008). Plasmon-enhanced solar energy conversion inorganic bulk hetero junction photovoltaics. Applied Physics Letters, 92, 013504-1-013504-3.

[22] Hagglund, C., Zach, M., \& Kasemo, B. (2008). Enhanced charge carrier generation in dye sensitized solar cells by nanoparticle plasmons. Applied Physics Letters, 92, 013113-1013113-3.

[23] Kalfagiannis, N., Karagiannidis, P. G., Pitsalidis, C., Panagiotopoulos, N. T., Gravalidis, C., Kassavetis, S., Patsalas, P., \& Logothetidis, S. (2012). Plasmonic silver nanoparticles for improved organic solar cells. Solar Energy Materials \& Solar Cells, 104, 165-174.

[24] Danladi, E., Ezeoke, J., Ahmad, M. S., Danladi, E. B., Sarki, S H., Iliyasu, I., \& Gyuk, P. M. (2016). Photoelectrochemical performance of dye-sensitized organic photovoltaic cells based on natural pigments and wide-bandgap nanostructured semiconductor. Physical Science International Journal, 10(2), $1-7$.

[25] Danladi, E., Onimisi, M. Y., Abdu, S. G., Ezeoke, J., \& Yakubu, S. O. (2016). Photoelectric characterization of a dye-sensitized solar cell based on natural pigment extracted from Roselle (Hibiscus sabdariffa) flower and $\mathrm{TiO}_{2}$ nanoparticles. British Journal of Applied Science \& Technology, 15(2), 1-6.

[26] Isah, H., Danladi, E., \& Gyuk, P. M. (2015). Development of Organic Dye Sensitized Solar Cell Incorporated with $\mathrm{TiO}_{2}$ Nanostructures with Low Conversion Efficiency for Exploring Solar Energy Concepts. International Journal of Optoelectronic Engineering, 5(1), 16-19.

[27] Danladi, E, Ahmad, M. S., Idodo, M., Danladi, E. B., Aungwa, F., \& Sarki, S. H. (2016). Dye-sensitized solar cells using natural dyes extracted from Roselle (Hibiscus sabdariffa) flowers and pawpaw (Carica papaya) leaves as sensitizers. Journal of Energy and Natural Resources, 5(1), 11-15.

[28] Danladi, E., Owolabi, J. A., Olowomofe, G. O., Onimisi, M. Y., \& Aungwa, F. (2016). Enhancement in Photovoltaic Parameters of a Dye Sensitized Solar Cell by Surface Plasmon
Resonance of Metallic Silver Nanoparticles. American Chemical Science Journal, 14(3), 1-8.

[29] Ezeoke, J., Onimisi, M. Y., Danladi, E., Abdu, S. G., \& Abdulsalam, M. S. (2016). Photovoltaic Perfomance of Dye Sensitized Solar Cells Using Natural Dyes Extracted from Bougainvillea Flower and Mango Leaves. Journal of Scientific Research \& Reports, 10(6), 1-5.

[30] Boyo, A., Paul, O., Abdulsalami, I., Surukite, O., Boyo, H. O., \& Boyo, H. (2013). Application of Hibiscus Sabdariffa and leaves of Azardirachta Indica calyxes as sensitizers in Dye sensitized solar cells. International Journal of Engineering Research and Development, 8(12), 38-42.

[31] Wongcharee, K., Meeyoo, V., \& Chavadej, S. (2007). Dye sensitized solar cell using natural dyes extracted from rosella and blue pea flowers. Solar energy materials and solar cells, 91(7), 566-571

[32] Mphande, B. C., \& Pogrebnoi, A. (2015). Outdoor photoelectrochemical characterization of dyes from Acalypha wilkesiana 'Haleakala' and Hibiscus sabdariffa as dye solar cells sensitizers. British Journal of Applied Science \& Technology, 7(2), 195-204.

[33] Zhou, H., Wu, L., Gao, Y., \& Ma, T. (2011). Dye-sensitized solar cells using 20 natural dyes as sensitizers. Journal of Photobiology A Chemistry 291, 188-194.

[34] Frank, T., Janssen, M., Netzel, M., Strass, G., Kler, A., Kriesl, E., \& Bitsch, I (2005). Pharmacokinetics of anthocyanins-3-glycosides following consumption of Hibiscus sabdariffa L. extract. The Journal of Clinical Pharmacology, 45(2), 203-210

[35] Terahara, N., Saito, N., Honda, T., Toki, K. \& Y. Osajima, (1990). Further structural elucidation of the anthocyanin, deacylternatin, from Clitoria ternatea. Phytochemistry, 29(11), 3686-3687.

[36] Zhao, J., Wang, A., \& Green, M. A. (1999). 24.5\% Efficiency Silicon PERT Cells on MCZ Substrates and $24.7 \%$ Efficiency PERL Cells on FZ Substrates. Progress in Photovoltaics, 7, 471-474. 